\title{
Taxonomic status of the leopard, Panthera pardus (Carnivora, Felidae) in the Caucasus and adjacent areas
}

\author{
Igor G. Khorozyan, Gennady F. Baryshnikov \& Alexei V. Abramov
}

\begin{abstract}
Nine subspecies names have been designated for the leopard in the Middle East: Arabian or South Arabian Panthera pardus nimr (Hemprich \& Ehrenberg, 1833); Anatolian or Asia Minor P. p. tulliana (Valenciennes, 1856); Caucasian P. p. ciscaucasica (Satunin, 1914); Persian or North Persian P.p. saxicolor Pocock, 1927; Sind or Baluchistan P. p. sindica Pocock, 1930; Kashmir P. p. millardi Pocock, 1930; Sinai P. p. jarvisi Pocock, 1932; Central Persian P. p. dathei Zukowsky, 1959 and South Caucasian $P$. p. transcaucasica Zukowsky, 1964. We have measured or retrieved data from literature on 24 characters and 3 indices of 40 leopard skulls originated from this region. We used multiple discriminant analysis to separate 7 groups from North Caucasus, South Caucasus, Turkmenistan, Iran, Turkey, Pakistan and Arabia with over $90 \%$ probabilities of correct group membership. Five scenarios of grouping were obtained which have shown the identity of the leopards from the Caucasus and Turkmenistan and their possible identity with individuals from northern Iran, closeness of leopards from southern Iran and Pakistan and from Turkey and Sinai Peninsula, and clear distinctiveness of the leopards from Arabia and Turkey from all other groups. In compliance with criteria of priority in zoological nomenclature, we suggest to retain the names $P$. $p$. ciscaucasica (=saxicolor, transcaucasica) for the Caucasus, Turkmenistan and northern Iran, $P$. p. tulliana for south-western Turkey, $P$. p. sindica (=dathei) for southern Iran and southern Pakistan and $P$. p. nimr for Arabian Peninsula. The subspecies $P$. p. millardi is probably synonymous to $P$. $p$. sindica and its status should be clarified on additional data. The taxonomic position of $P$. p. jarvisi should be verified by comparison with nominotypical $P$. p. pardus from Egypt.
\end{abstract}

KEY WORDS: leopard, Panthera pardus, geographic variability, taxonomy, Caucasus, conservation.

Igor G. Khorozyan [leopard_am@yahoo.com], Gennady F. Baryshnikov [ursus@zin.ru], and Alexei V. Abramov [aav@aa2510.spb.edu], Zoological Institute, Russian Academy of Sciences, Universitetskaya nab. 1, Saint Petersburg 199034, Russia.

\section{Таксономический статус леопарда, Panthera pardus (Carnivora, Felidae) Кавказа и сопредельных территорий}

\section{И.Г. Хорозян, Г.Ф. Барышников, А.В. Абрамов}

РЕЗЮМЕ. Для Передней Азии отмечены девять подвидов леопарда: аравийский или южно-аравийский Panthera pardus nimr (Hemprich \& Ehrenberg, 1833); анатолийский или малоазиатский P. $p$. tulliana (Valenciennes, 1856); кавказский P. p. ciscaucasica (Satunin, 1914); персидский или североперсидский P. p. saxicolor Pocock, 1927; синдский или белуджистанский P. p. sindica Pocock, 1930; кашмирский P. p. millardi Pocock, 1930; синайский P. p. jarvisi Pocock, 1932; центрально-персидский P. p. dathei Zukowsky, 1959 и южно-кавказский P. p. transcaucasica Zukowsky, 1964. Мы измерили музейные экземпляры и проанализировали литературные данные по 24 параметрам и 3 индексам у 40 черепов, происходящих из данного региона. Мы использовали дискриминантный анализ для разделения 7 групп из Северного Кавказа, Южного Кавказа, Туркменистана, Ирана, Турции, Пакистана и Аравии с более чем 90\% вероятностью правильной классификации по группам. Были получены пять сценариев распределения черепов по группам, которые показали идентичность леопардов из Кавказа и Туркменистана и их вероятную идентичность с особями из северного Ирана, близость леопардов из южного Ирана и Пакистана и из Турции и Синайского полуострова и четкую обособленность леопарда из Турции и Аравии от всех других групп. В соответствии с правилом приоритета зоологической номенклатуры, мы предлагаем закрепить названия P. p. ciscaucasica (=saxicolor, transcaucasica) для Кавказа, Туркменистана и северного Ирана, P. p. sindica (=dathei) для южного Ирана и южного Пакистана и P. p. nimr для Аравийского полуострова. Подвид P. $p$. millardi, вероятно, является синонимом $P$. p. sindica и его статус должен быть выяснен на дополнительном материале. Таксономическое положение $P$. p. jarvisi может быть уточнено после сравнения с номинативным подвидом P. p. pardus из Египта.

КЛЮЧЕВЫЕ СЛОВА: леопард, Panthera pardus, географическая изменчивость, таксономия, Кавказ, охрана. 


\section{Introduction}

The leopard Panthera pardus (Linnaeus, 1758) has been teetering on the brink of extinction in the Middle East. Formerly widespread across a variety of habitats, it is now distributed only in several countries and numbers no more than 1300 individuals (Khorozyan \& Abramov, 2005; Khorozyan et al., 2005). According to the last global survey of the leopard status made by Shoemaker (1993), this predator can be classified as "rare" in Iran, Afghanistan and Pakistan, "endangered" in Israel, Oman, Saudi Arabia, Caucasus countries, Yemen and Turkmenistan and "extinct" in Iraq, $\mathrm{Ku}$ wait, Lebanon, Qatar, Turkey, UAE, Jordan, and Syria. The core population lives in Iran where 550-850 leopards are guesstimated (Kiabi et al., 2002).

In the Caucasus, which is of special emphasis for us, the areas of certain leopard presence include southern Armenia from Khosrov Nature Reserve to the Armenian-Iranian state border and two distinct areas in Azerbaijan (Talysh Mountains and Zangezour Ridge in Nakhichevan Republic). However, the records beyond Armenia and Azerbaijan are also documented. In April 2001, an adult female was shot on the border between Georgia and Kabardino-Balkaria in Russia and her two male cubs were captured and delivered to Novosibirsk Zoo where they are being maintained now (Lukarevsky et al., 2004; Raffel, 2004). In 2004 and 2005, seven photo-trap pictures of the young male leopard were taken in Vashlovani Nature Reserve of extreme southeast of Georgia (B. Lortkipanidze, pers. comm.). Anecdotal records come also from Nagorno-Karabakh Republic, Daghestan's Avarskoe Koisu River headwaters and Ingushetiya's Erzu Nature Reserve (Lukarevsky, 2006; A. Malkhasyan, pers. comm.).

So, contemporary leopard range in the region extends over the southern South Caucasus and the eastern North Caucasus. South Caucasus (formerly known as the Transcaucasus) includes three countries - Armenia, Azerbaijan and Georgia. North Caucasus incorporates the small republics within the Russian Federation which lie on the northern side of the Great Caucasus Ridge. Total leopard population size in this region is unlikely to exceed 30 individuals (Khorozyan et al., 2005).

The present communication deals with the taxonomy of leopard from the Middle East. To many, unclear taxonomic position of subspecies would seem to be an issue of pure academic interest far distant from the needs of modern conservation. As some believe, taxonomy and conservation can be linked only in those rare cases when geographically isolated populations, e.g. on islands, are represented by distinct taxa (Anonymous, 1991). However, this issue has much broader implications. Recognition of well-justified species and subspecies as the candidates for priority research and conservation is an indispensable managerial tool in conditions of insufficient funding (Anonymous, 1991; O’Brien \& Mayr, 1991).

Recently, two aspects illustrating the closeness of taxonomy and conservation have emerged in case of the leopard in the Caucasus. First, introduction of two aforementioned grown-up cubs from Novosibirsk Zoo to the breeding program within the Persian Leopard Studbook has been delayed until their taxonomic status and relation to the Persian leopard are clarified (Raffel, 2004). As this studbook states, they remain to be the only wild-caught leopards from the Middle East and must be considered as valuable founders. And, second, the plans to use captive Persian leopards in a program of reintroduction to the western North Caucasus have been criticized by some experts insisting on distinctiveness of the Caucasus and Persian leopards (Lukarevsky, 2006).

The question "which leopard subspecies lives in the Caucasus?" is not trivial. Different authors used the names Caucasian leopard P. p. ciscaucasica (Satunin, 1914) for the cats in North Caucasus, Anatolian or Asia Minor leopard P. p. tulliana (Valenciennes, 1856) for the cats in South Caucasus and Persian or North Persian leopard P. p. saxicolor Pocock, 1927 for the Caucasus in general (Khorozyan et al., 2005). Anatolian leopard was described first in extreme west of Asia Minor, near Izmir in Turkey (Valenciennes, 1856), so the remoteness of this terra typica can raise a dubiety in validity of its name for the cats from the Caucasus. Caucasian leopard was discovered by Satunin (1914) on a basis of specimens from the Kuban region of North Caucasus (sintypes: skin without number from Psebai and male skull without number from Kiban region; their whereabouts is not known) as morphologically distinct from Anatolian subspecies, but small sample size used for comparison does not give a ground for firm conclusions. Persian leopard was described last, but from much more abundant material across Iran (former Persia), and is known to be linked with the Caucasus population (Pocock, 1930a). Before this publication, we named the leopard in the Caucasus as Persian leopard P. p. saxicolor to indicate its connectedness with Iran (Khorozyan \& Abramov, 2005). Some authors (Miththapala, 1992; Miththapala et al., 1996; Uphyrkina et al., 2001) claim that all leopards living in the Middle East, except the Arabian or South Arabian leopard P. p. nimr (Hemprich \& Ehrenberg, 1833) whose distinctiveness was proved by molecular genetics, should be assigned a single name $P$. p. saxicolor as no significant geographical barriers allow for morphogenetic isolation of subspecies in this region. However, small sample size taken by these authors mostly from the zoos did not shed light on uncertain leopard systematics in the Middle East.

In this paper, we provide the first information on a comparative analysis of the leopard skulls and skins from the Caucasus and adjacent areas of the Middle East and discuss the taxonomic position of the leopard in this region.

\section{Material and methods}

The examined material is housed at the Zoological Institute of the Russian Academy of Sciences, SaintPetersburg, Russia (ZIN), Zoological Museum of the 


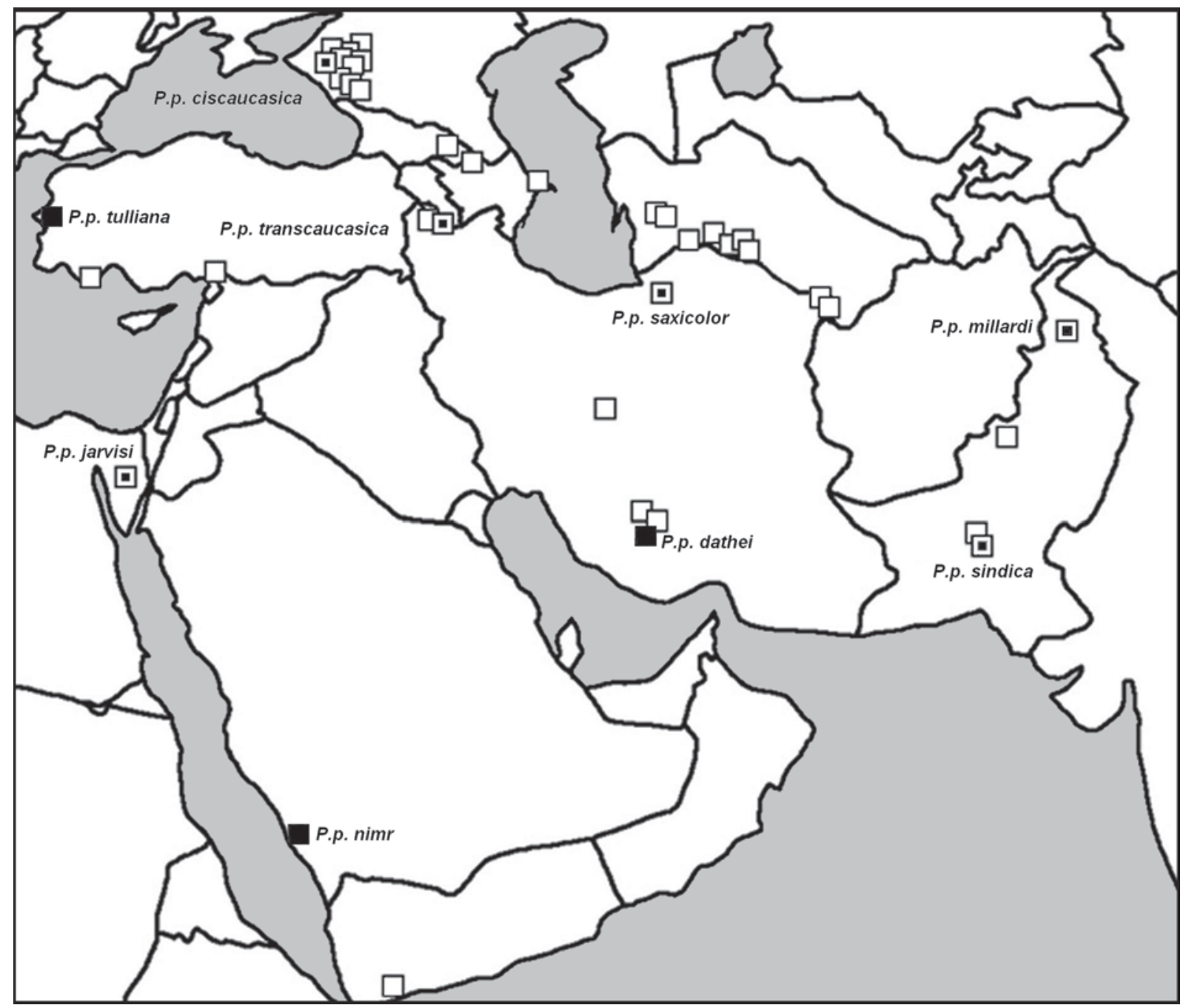

Figure 1. The localities of the leopard skulls from the Middle East used in this study. The terra typica are shown by white quadrates with black centers for the skulls in our study materials and by black quadrates for other subspecies. Four skulls whose origin is indicated by country only ( 3 from Turkmenistan and 1 from Iran) are not shown here.

Moscow State University, Moscow, Russia (ZMMU), Municipal Museum, Stavropol, Russia (MUM), S. Janashia State Museum, former Caucasus Museum, Tbilisi, Georgia (JSM), Natural History Museum, Baku, Azerbaijan (NHMB), Natural History Museum, London, UK (NHM) and in private collections. The map depicting the origin sites of these skulls is provided in Fig. 1. Forty leopard skulls used in this study were sorted out in the 7 geographical groups and included the following specimens:

North Caucasus, Russia ( $\mathrm{n}=10)$ : without coll. No.*, sintype $P$. p. ciscaucasica (Satunin, 1914), adult male, Kuban region (N.Ya. Dinnik's private collection); without coll. No.*, adult female, Kuban region (Dinnik's private collection); without coll. No.*, subadult female, Kuban region (Dinnik's private collection); JSM 37f***, adult, sex unknown, Psebai, Kuban region; ZIN 5744***, adult male, junction of Umpyr and Malaya Laba rivers, Kuban region; ZIN $5745^{* * *}$, adult female, junction of
Umpyr and Malaya Laba rivers, Kuban region; ZIN $5742 * * *$, adult, sex unknown, Kuban region; ZIN 9380***, adult, sex unknown, Sakhrai River, Tam-dee, Maikop District, Kuban region; ZMMU S-150163***, adult, sex unknown, Maikop District, Kuban region; MUM 149*, adult, sex unknown, Kuban region.

South Caucasus $(\mathrm{n}=5)$ : JSM $37^{*}$, holotype $P . p$. transcaucasica Zukowsky, 1964, adult, sex unknown, Julfa, Erivan Province (now in Nakhichevan Republic, Azerbaijan); JSM 37a***, adult, sex unknown, Julfa, Erivan Province (now in Nakhichevan Republic, Azerbaijan); MUM without coll. No.*, adult male, Jara Canyon, Zakataly District, Azerbaijan; NHMB 2117***, adult male, Bilga Village, Apsheron Peninsula, Azerbaijan; ZIN 9378***, adult male, Lagodekhi, Georgia.

Turkmenistan $(\mathrm{n}=12)$ : ZIN 9381***, adult male, Bolshye Balkhany Mountains; ZIN 17962***, adult female, Chandyr riverside, Yargi-Kala Village, Western Kopetdag Mountains; ZIN 27712***, adult, sex 

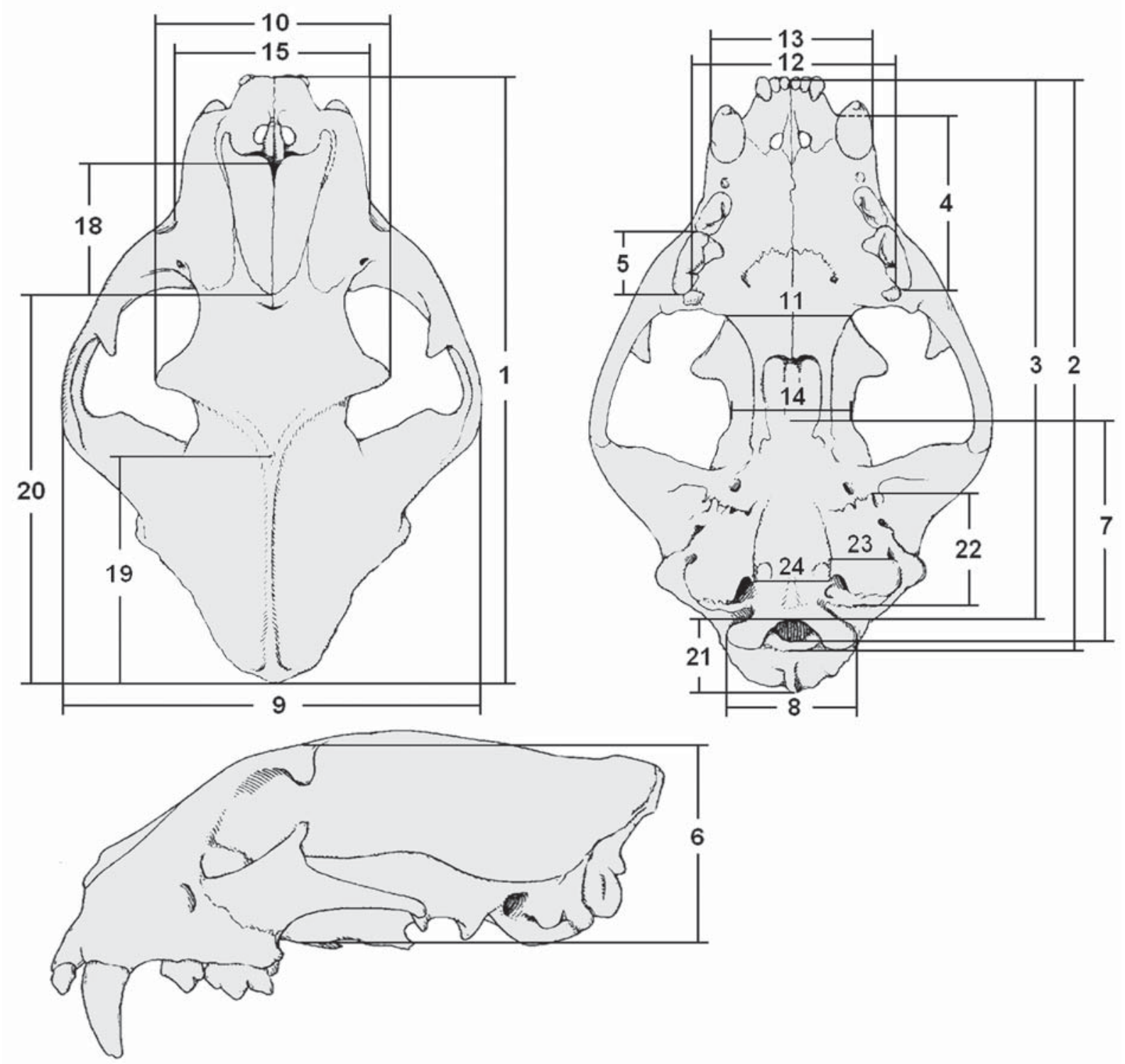

Figure 2. The cranial measurements of Panthera pardus used in this study.

1 - greatest length; 2 - condylobasal length; 3 - basal length; 4 - length of upper tooth row C-P4; 5 - greatest length of carnassial P4; 6 - skull height at the supraorbital processes; 7 - length of the braincase from opisthion to postorbital constriction; 8 - greatest breadth of the occipital condyles; 9 - zygomatic breadth; 10 - frontal breadth; 11 - minimal interorbital breadth; 12 - greatest palatal breadth posterior to P4, alveoli included; 13 - rostrum breadth, alveoli included; 14 - minimal breadth of the postorbital constriction; 15 breadth between the infraorbital foramina; 16 - vertical diameter of the infraorbital foramina; 17 - horizontal diameter of the infraorbital foramina; 18 - minimum length of the nasals (suture length); 19 - length between opistocranion and bregma; 20 - length between opistocranion and nasion; 21 - length between opistocranion and basion; 22 - length of bulla ossae; 23 — width of bulla ossae; 24 breadth between bulla ossae. The measurements 16 and 17 are not displayed.

unknown, Badkhyz Nature Reserve; ZIN 26180***, adult, sex unknown, Nebit-dag; ZIN 35177***, adult, sex unknown, Turkmenistan; ZIN 35178***, adult, sex unknown, Turkmenistan; ZMMU S-43330***, adult female, Doshtoi Canyon, Central Kopetdag Mountains; ZMMU S-45916***, adult female, $15 \mathrm{~km}$ from Yablonovka Village, Babazau Canyon, Central Kopetdag Mountains; ZMMU S-51945***, adult, sex unknown, Central Kopetdag Mountains; ZMMU S51946***, adult, sex unknown, Turkmenistan; ZMMU
S-111028***, adult, sex unknown, Badkhyz Nature Reserve; ZMMU S-152549***, adult, sex unknown, canyon $2 \mathrm{~km}$ from Aidere Village, Kara-Kala District, Kopetdag Mountains.

Iran $(n=5)$ : without coll. No.*, adult male, Mishun, Fars Province (C.E. Capito's private collection); ZMMU S-35002***, adult male, Persia (from Moscow Zoo); NHM 82.11.3.4**, holotype P. p. saxicolor Pocock, 1927, adult male (Pocock, 1930a), near Asterabad (now Gorgan); NHM 1937.11.9.1**, adult, sex unknown, 
Mishun, Fars Province; NHM 55.1182**, adult, sex unknown, Kuhpaieh.

Turkey $(n=2)$ : NHM 80.2.16.1**, adult female (Pocock, 1930a; Kumerloeve, 1956), Giaour Dagh, near Osmanieh; NHM 73.28**, adult, sex unknown, Finike.

Pakistan $(\mathrm{n}=4)$ : NHM 91.10.7.8**, holotype $P . p$. sindica Pocock, 1930, subadult male (Pocock, 1930a), Kirthar Range, Sind; NHM without coll. No.*, adult female, Kirthar Range, Sind; NHM 25.1.3.2**, holotype P. p. millardi Pocock, 1930, adult female, Kashmir; NHM 34.8.12.1**, adult male, Kushnob, Baluchistan.

Arabia (n=2): NHM 29.12.23.2**, holotype P.p. jarvisi Pocock, 1932, adult female, Sinai Peninsula; NHM 55.428**, adult male, W. Wishem, Aden.

Data on the skulls marked by one asterisk (*) were retrieved from literature (Satunin, 1905, 1915; Dinnik, 1914; Pocock, 1930a, b; Ognev, 1935; Alekperov, 1947; Burchak-Abramovich \& Jafarov, 1949) and were collected from a limited number of characters (from 4 to 18 per skull). Pocock's (1930) measurements originally provided in inches were transformed as 1 inch $=25 \mathrm{~mm}$. The skulls marked by two asterisks $(* *)$ were measured for 11 characters. In the skulls marked by three asterisks (***), all 24 cranial characters were measured or data on them were obtained from Burchak-Abramovich \& Jafarov (1949).

Twenty-four measurements of the cranium (Fig. 2) were taken in mm by Vernier calipers with accuracy $0.05 \mathrm{~mm}$. Three cranial indices were calculated: ratio of zygomatic breadth to basal length $\times 100 \%$; ratio of postorbital constriction breadth to basal length $\times 100 \%$; ratio of postorbital constriction to minimal interorbital breadth.

Twelve skulls (JSM 37f, JSM 37a, NHMB 2117 , ZIN 9380, ZIN 5742, ZIN 5744, ZIN 9381, ZIN 5745, ZIN 9378, NHM 80.2.16.1, NHM 91.10.7.8 and NHM 25.1.3.2) were measured independently by different authors (Satunin, 1905, 1915; Dinnik, 1914; Pocock, 1930a, b; Ognev, 1935; Alekperov, 1947; BurchakAbramovich \& Jafarov, 1949) and us. To study the effect of observer bias on the measurement errors, we used the $\chi^{2}$ test of the same-character measurements.

Multiple discriminant analysis (MDA) was employed to determine the general leopard grouping patterns in the Middle East, estimate their statistical robustness and find the cranial measurements most important for this grouping (Puzachenko, 1993; Larson, 1997; Quinn \& Keough, 2002; Meijaard, 2004; Yamaguchi et al., 2004). Ten cranial characters and one cranial index which were measured in the sample of 31 specimens best represented across the groups were chosen and analyzed by MDA. This sample included the specimens JSM 37f, ZIN 5744, ZIN 9380, ZIN 5745, ZIN 5742, ZMMU S-150163, MUM 149, JSM 37a, NHMB 2117 , ZIN 9378, ZIN 9381, ZIN 17962, ZIN 27712, ZIN 26180, ZIN 35177, ZIN 35178, ZMMU S-43330, ZMMU S-45916, ZMMU 51945, ZMMU S-51946, ZMMU S-111028, ZMMU S-152549, NHM 82.11.3.4, NHM 1937.11.9.1, NHM 55.1182, NHM 80.2.16.1,
NHM 73.28, NHM 25.1.3.2, NHM 34.8.12.1, NHM 29.12.23.2 and NHM 55.428. The ten characters were the greatest length, condylobasal length, and length of upper tooth row, zygomatic breadth, minimal interorbital breadth, greatest palatal breadth, rostrum breadth, and minimal breadth of postorbital constriction, length of bulla ossae and width of bulla ossae. The index was the ratio of postorbital constriction to minimal interorbital breadth. All relevant procedures were done in SPSS 9.0 statistical package.

To investigate how variable are the leopard skins in the Middle East, we have compiled from literature, museums, photo-trap pictures and pictures of captive animals information on 64 individuals which included 7 from Turkey, 20 from Iran, 11 from North Caucasus, 5 from Turkmenistan, 13 from South Caucasus (8 Armenia, 4 - Azerbaijan, 1 - Georgia) and 8 from the zoos: Zoological Center of Tel Aviv at Ramat Gan (Israel), Parc Zoologique de la Barben (France), Tierpark Nordhorn (Germany), Yerevan Zoo (Armenia), Płock Miejski Ogród Zoologiczny (Poland), and Tierpark Klingenthal (Germany).

\section{Results}

Cranial variation. Measuring the same cranial characters by different researchers did not produce significant measurement errors around their mean values $\left(n=160\right.$ paired measurements, $\chi^{2}$ varied from 0 to 1.201 , $\mathrm{P}$ varied from 1 to 0.273 ).

We failed to analyze the sexual dimorphism in leopard skulls within the groups, as even the largest sample from Turkmenistan had insufficient number of specimens with known sex and three groups (Turkey, South Caucasus and Iran) did not have the representatives of either sex. Also, as our study materials included only one juvenile male and one juvenile female, we did not analyze the effect of age on leopard skull size.

Considering the ambiguity of sex-related differences in the studied skulls and the risk of losing information from unsexed specimens which made up 45\% (18 out of 40) of total sample, we have performed the MDA of 31 skulls as indicated in Material and Methods. Assumption of equal prior probabilities for all groups was taken as a rule. Statistical information about the measurements is given in Tab. 1 and the results of MDA are provided in Tab. 2 and Fig. 3.

Five scenarios of leopard grouping in the Middle East were obtained whose probabilities of correct group membership, also known as posterior probabilities, were over $90 \%$ (Tab. 2, Fig. 3). They were ranged from the lowest to the highest posterior probabilities. Condylobasal length was the principal cranial character discriminating the leopard groups, followed by greatest length, interorbital breadth, rostrum breadth, zygomatic breadth and greatest palatal breadth (Tab. 2).

The scenario 1 represented the separation of leopard population into the 7 groups of North Caucasus, South Caucasus, Turkmenistan, Iran, Turkey, Pakistan and Arabia. Its posterior probability was $93.5 \%$. The 
Table 1. Measurements of the leopard Panthera pardus skulls. The characters are numbered (\#) as in Fig. 2. Indices: 25 ratio of zygomatic breadth to basal length $\times 100 \% ; 26$ — ratio of postorbital constriction breadth to basal length $\times 100 \%$; 27 - ratio of postorbital constriction to minimal interorbital breadth. Abbreviations: $\mathrm{x}$ - mean, SE — standard error; $\mathrm{n}$ - number of measured specimens.

\begin{tabular}{|c|c|c|c|c|c|c|c|c|c|c|c|c|c|c|c|c|c|}
\hline \multirow{3}{*}{ \# } & \multicolumn{11}{|c|}{ P. p. ciscaucasica } & \multicolumn{6}{|c|}{ P. p. sindica } \\
\hline & \multicolumn{3}{|c|}{ North Caucasus } & \multicolumn{3}{|c|}{ South Caucasus } & \multicolumn{3}{|c|}{ Turkmenistan } & \multicolumn{2}{|c|}{ Northern Iran } & \multicolumn{3}{|c|}{ Southern Iran } & \multicolumn{3}{|c|}{ Southern Pakistan } \\
\hline & $\mathrm{x}$ & SE & $\mathrm{n}$ & $\mathrm{x}$ & SE & $\mathrm{n}$ & $\mathrm{x}$ & $\mathrm{SE}$ & $\mathrm{n}$ & $\mathrm{x}$ & $\mathrm{n}$ & $\mathrm{x}$ & SE & $\mathrm{n}$ & $\mathrm{x}$ & SE & $\mathrm{n}$ \\
\hline 1 & 216.3 & 4.8 & 10 & 237.1 & 10.0 & 5 & 217.3 & 5.5 & 12 & 225.1 & 1 & 227.9 & 15.7 & 2 & 212.0 & 10.9 & 3 \\
\hline 2 & 198.4 & 5.1 & 7 & 207.3 & 8.4 & 4 & 197.7 & 4.6 & 12 & 201.1 & 1 & 206.7 & 12.1 & 2 & 191.9 & 16.9 & 2 \\
\hline 3 & 181.5 & 4.8 & 10 & 199.3 & 7.1 & 5 & 185.4 & 4.5 & 12 & & & & & & & & \\
\hline 4 & 68.4 & 1.7 & 7 & 71.9 & 2.5 & 4 & 68.5 & 1.5 & 12 & 68.8 & 1 & 71.1 & 2.3 & 2 & 71.6 & 1.6 & 2 \\
\hline 5 & 24.5 & 0.4 & 7 & 24.9 & 1.1 & 4 & 24.6 & 0.5 & 12 & & & & & & 23.0 & & \\
\hline 6 & 72.8 & 1.9 & 7 & 76.9 & 0.2 & 2 & 74.1 & 1.5 & 12 & & & & & & & & \\
\hline 7 & 97.1 & 1.5 & 7 & 96.1 & 5.0 & 3 & 106.5 & 2.1 & 12 & & & & & & & & \\
\hline 8 & 42.2 & 0.9 & 6 & 44.9 & 1.6 & 3 & 42.3 & 0.7 & 12 & & & & & & & & \\
\hline 9 & 137.3 & 4.0 & 10 & 152.7 & 6.5 & 5 & 143.1 & 3.5 & 12 & 139.5 & 1 & 144.4 & 9.8 & 2 & 134.4 & 7.0 & 3 \\
\hline 10 & 72.5 & 1.7 & 7 & 72.8 & 2.8 & 3 & 71.9 & 1.5 & 12 & & & & & & & & \\
\hline 11 & 43.9 & 1.3 & 10 & 46.8 & 1.8 & 5 & 42.8 & 1.0 & 12 & 37.6 & 1 & 45.1 & 1.6 & 2 & 41.2 & 1.2 & 2 \\
\hline 12 & 69.8 & 2.6 & 7 & 71.4 & 2.0 & 3 & 69.8 & 1.3 & 12 & 81.0 & 1 & 80.9 & 3.6 & 2 & 81.2 & 1.8 & 2 \\
\hline 13 & 54.7 & 2.1 & 7 & 57.4 & 3.1 & 4 & 53.0 & 1.5 & 12 & 54.2 & 1 & 57.6 & 3.3 & 2 & 59.0 & 2.8 & 2 \\
\hline 14 & 46.0 & 0.9 & 7 & 47.9 & 1.1 & 4 & 45.2 & 0.5 & 12 & 43.2 & 1 & 42.8 & 0.2 & 2 & 45.6 & 0.1 & 2 \\
\hline 15 & 61.3 & 1.4 & 7 & 63.9 & 1.5 & 3 & 60.3 & 1.4 & 12 & & & & & & & & \\
\hline 16 & 8.5 & 0.6 & 6 & 8.4 & 0.9 & 3 & 7.9 & 0.3 & 12 & & & & & & & & \\
\hline 17 & 8.3 & 0.2 & 6 & 8.3 & 0.6 & 3 & 7.1 & 0.3 & 12 & & & & & & & & \\
\hline 18 & 48.5 & 1.2 & 7 & 47.7 & 1.4 & 3 & 46.6 & 1.3 & 12 & & & & & & & & \\
\hline 19 & 86.3 & 3.3 & 6 & 87.6 & 8.7 & 3 & 96.5 & 3.5 & 12 & & & & & & & & \\
\hline 20 & 146.0 & 3.8 & 6 & 153.2 & 9.1 & 3 & 147.7 & 3.9 & 12 & & & & & & & & \\
\hline 21 & 55.0 & 1.4 & 6 & 59.8 & 2.8 & 3 & 56.1 & 1.5 & 12 & 62.4 & 1 & 63.1 & 2.8 & 2 & 63.7 & & 1 \\
\hline 22 & 34.9 & 0.8 & 7 & 35.3 & 0.7 & 3 & 36.2 & 1.0 & 12 & 34.8 & 1 & 34.5 & 2.7 & 2 & 37.1 & & 1 \\
\hline 23 & 22.5 & 0.7 & 7 & 21.9 & 2.4 & 3 & 22.3 & 1.2 & 12 & 23.7 & 1 & 22.5 & 1.5 & 2 & 22.9 & & 1 \\
\hline 24 & 25.0 & 0.9 & 7 & 26.6 & 0.5 & 3 & 24.8 & 0.7 & 12 & & & & & & & & \\
\hline 25 & 75.6 & 0.7 & 7 & 75.4 & 0.7 & 3 & 77.2 & 0.8 & 12 & & & & & & & & \\
\hline 26 & 25.0 & 0.8 & 7 & 24.6 & 1.1 & 3 & 24.6 & 0.7 & 12 & & & & & & & & \\
\hline 27 & 1.0 & 0.0 & 7 & 1.0 & 0.0 & 3 & 1.1 & 0.0 & 12 & 1.1 & 1 & 1.0 & 0.1 & 2 & 1.1 & 0.0 & 2 \\
\hline
\end{tabular}

leopards of the North Caucasus group had the highest posterior probability of belonging to their own group (6 out of 7 specimens, $85.7 \%$ ) and much lower of belonging to the South Caucasus group (1 out of 7, 14.3\%). In the Turkmenistan group, posterior probability of belonging to its group dominated over belonging to the North Caucasus group (11 out of $12,91.7 \%$ and 1 out of $12,8.3 \%$, respectively). In the South Caucasus, Iran, Pakistan, Turkey and Arabia groups, all $100 \%$ of original cases were correctly classified under this scenario.

The scenario 2 split the population into the 4 groups of the Caucasus, Turkmenistan and northern Iran, southern Iran and Pakistan, Turkey, and Arabia. Its posterior probability was $93.5 \%$. The posterior probability of the first group was the highest of belonging to its group (21 out of 23 specimens, $91.3 \%$ ) and lower of belonging to the southern Iran and Pakistan group (2 out of 23, $8.7 \%)$. As previously, the Turkey and Arabia groups had perfect $(100 \%)$ posterior probability.

The scenario 3 implied the separation into the 4 groups of the Caucasus, Turkmenistan and northern Iran, southern Iran and Pakistan, Turkey and Sinai Peninsula, and Arabia. Its posterior probability was $96.8 \%$. The specimens of the first group had much higher posterior probability of belonging to its group (22 out of 23 specimens, $95.7 \%$ ) than to the southern Iran and Pakistan group (1 out of 23, 4.3\%). All other groups had $100 \%$ probabilities. 
Table 1 (continuing).

\begin{tabular}{|c|c|c|c|c|c|c|c|c|c|}
\hline \multirow{3}{*}{ \# } & \multicolumn{2}{|c|}{ P. p. millardi } & \multicolumn{3}{|c|}{ P. p. tulliana } & \multicolumn{2}{|c|}{ P. p. jarvisi } & \multicolumn{2}{|c|}{ P. p. nimr } \\
\hline & \multicolumn{2}{|c|}{ Kashmir } & \multicolumn{3}{|c|}{ South-western Turkey } & \multicolumn{2}{|c|}{ Sinai } & \multicolumn{2}{|c|}{ Arabian Peninsula } \\
\hline & $\mathrm{x}$ & $\mathrm{n}$ & $\mathrm{x}$ & SE & $\mathrm{n}$ & $\mathrm{x}$ & $\mathrm{n}$ & $\mathrm{x}$ & $\mathrm{n}$ \\
\hline 1 & 207.8 & 1 & 212.9 & 4.7 & 2 & 194.0 & 1 & 164.1 & 1 \\
\hline 2 & 187.7 & 1 & 192.5 & 2.1 & 2 & 178.1 & 1 & 150.3 & 1 \\
\hline 3 & & 1 & & & & & 1 & & 1 \\
\hline 4 & 64.4 & 1 & 64.8 & 2.0 & 2 & 60.9 & 1 & 52.5 & 1 \\
\hline 5 & 24.0 & 1 & 23.0 & & 1 & & & & \\
\hline \multicolumn{10}{|l|}{6} \\
\hline \multicolumn{10}{|l|}{7} \\
\hline \multicolumn{10}{|l|}{8} \\
\hline 9 & 135.9 & 1 & 138.9 & 6.4 & 2 & 127.4 & 1 & 105.5 & 1 \\
\hline 10 & & & & & & & 1 & & 1 \\
\hline 11 & 36.8 & 1 & 46.1 & 4.5 & 2 & 41.0 & 1 & 32.7 & 1 \\
\hline 12 & 81.0 & 1 & 78.2 & 1.8 & 2 & 71.6 & 1 & 64.1 & 1 \\
\hline 13 & 52.6 & 1 & 55.6 & 1.9 & 2 & 49.8 & 1 & 41.1 & 1 \\
\hline 14 & 43.4 & 1 & 45.3 & 0.5 & 2 & 44.0 & 1 & 37.3 & 1 \\
\hline \multicolumn{10}{|l|}{15} \\
\hline \multicolumn{10}{|l|}{16} \\
\hline \multicolumn{10}{|l|}{17} \\
\hline \multicolumn{10}{|l|}{18} \\
\hline \multicolumn{10}{|l|}{19} \\
\hline \multicolumn{10}{|l|}{20} \\
\hline 21 & 61.6 & 1 & 59.0 & & 1 & 58.0 & 1 & 52.0 & 1 \\
\hline 22 & 33.5 & 1 & 33.5 & 0.0 & 2 & 30.1 & 1 & 28.1 & 1 \\
\hline 23 & 21.3 & 1 & 21.5 & 0.2 & 2 & 22.0 & 1 & 18.2 & 1 \\
\hline \multicolumn{10}{|l|}{24} \\
\hline \multicolumn{10}{|l|}{25} \\
\hline \multicolumn{10}{|l|}{26} \\
\hline 27 & 1.2 & 1 & 1.0 & 0.1 & 2 & 1.1 & 1 & 1.1 & 1 \\
\hline
\end{tabular}

Two scenarios had $100 \%$ performance of correct group membership. The scenario 4 consisted of the five groups of the Caucasus and Turkmenistan, Iran, Turkey, Pakistan, and Arabia. The scenario 5 divided the population into the five groups of the Caucasus and Turkmenistan, Iran, Turkey and Sinai Peninsula, Pakistan, and Arabia.

The North Caucasus leopard skulls had significantly smaller greatest length and basal length than the South Caucasus counterparts (one-tail: $\mathrm{t}=-2.14$ and $\mathrm{t}=$ $-2.10, \mathrm{df}=13$ in each case, $\mathrm{P}<0.05)$. Their zygomatic breadth was significantly narrower (one-tail: $\mathrm{t}=-2.13$, $\mathrm{df}=13, \mathrm{P}<0.05)$. Condylobasal length and frontal breadth of the leopard skulls from both these regions did not differ (two-tail: $\mathrm{P}>0.1$ ).
The South Caucasus leopard skulls were significantly larger than those from Turkmenistan and Pakistan in greatest length (one-tail: $\mathrm{t}=1.88, \mathrm{df}=15, \mathrm{P}<0.05$ and $\mathrm{t}=1.98, \mathrm{df}=7, \mathrm{P}<0.05$, respectively) and from Pakistan in zygomatic breadth (one-tail: $\mathrm{t}=2.09, \mathrm{df}=7, \mathrm{P}$ $<0.05)$. No difference was found between the South Caucasus, Iran, Turkey, Turkmenistan and Pakistan skulls in condylobasal length, between South Caucasus, Iran, Turkey and Turkmenistan in zygomatic breadth and between South Caucasus, Iran and Turkey in greatest length (two-tail: $\mathrm{P}>0.1$ ).

Pelage coloration. Most of investigated animals $(73.4 \%)$ had grayish-yellow coloration. The animals with richer and bright tawny coat $(17.2 \%)$ came not only from Mediterranean coastal areas of south-west- 
Table 2. The multiple discriminant analysis summary of 5 scenarios of separating the leopard groups in the Middle East. Abbreviations: $\mathrm{df}$ — degree of freedom, SDC — standardized discriminant coefficient, Sig — significance level at $\mathrm{P}<0.05$.

\begin{tabular}{|c|c|c|c|c|c|c|c|c|c|c|c|c|c|}
\hline \multirow{2}{*}{$\begin{array}{l}\text { Discriminant } \\
\text { functions }\end{array}$} & \multirow{2}{*}{$\begin{array}{l}\text { Eigen- } \\
\text { value }\end{array}$} & \multirow{2}{*}{$\begin{array}{c}\% \text { of } \\
\text { variance }\end{array}$} & \multirow{2}{*}{$\begin{array}{l}\text { Canonical } \\
\text { correlation }\end{array}$} & \multirow{2}{*}{$\begin{array}{l}\text { Wilk's } \\
\text { lambda }\end{array}$} & \multirow{2}{*}{$\chi^{2}$} & \multirow{2}{*}{ df } & \multicolumn{6}{|c|}{3 most important characters with highest SDCs } & \multirow{2}{*}{ Sig. } \\
\hline & & & & & & & character & SDC & character & SDC & character & SDC & \\
\hline \multicolumn{14}{|c|}{ Scenario 1. Separation into 7 groups (North Caucasus; South Caucasus; Turkmenistan; Iran; Turkey; Pakistan; Arabia) } \\
\hline Function 1 & 15.30 & 77.6 & 0.97 & 0.004 & 117.3 & 66 & \begin{tabular}{|l|} 
condyloba- \\
sal length
\end{tabular} & 6.08 & $\begin{array}{l}\text { greatest } \\
\text { length }\end{array}$ & 5.97 & $\begin{array}{l}\text { zygomatic } \\
\text { breadth }\end{array}$ & 3.08 & 0.000 \\
\hline \multicolumn{14}{|c|}{ Scenario 2. Separation into 4 groups (Caucasus, Turkmenistan and northern Iran; southern Iran and Pakistan; Turkey; Arabia) } \\
\hline Function 1 & 5.74 & 83.5 & 0.92 & 0.061 & 63.0 & 33 & $\begin{array}{l}\text { condyloba- } \\
\text { sal length }\end{array}$ & 3.81 & $\begin{array}{l}\text { minimal } \\
\text { interorbital } \\
\text { breadth }\end{array}$ & 2.46 & $\begin{array}{l}\text { greatest } \\
\text { length }\end{array}$ & 2.21 & 0.001 \\
\hline \multicolumn{14}{|c|}{ Scenario 3. Separation into 4 groups (Caucasus, Turkmenistan and northern Iran; southern Iran and Pakistan; Turkey and Sinai; Arabia) } \\
\hline Function 1 & 7.39 & 81.0 & 0.94 & 0.035 & 75.7 & 33 & $\begin{array}{c}\text { condyloba- } \\
\text { sal length }\end{array}$ & 6.65 & $\begin{array}{l}\text { greatest } \\
\text { length }\end{array}$ & 3.50 & $\begin{array}{l}\text { rostrum } \\
\text { breadth }\end{array}$ & 2.55 & 0.000 \\
\hline \multicolumn{14}{|c|}{ Scenario 4. Separation into 5 groups (Caucasus and Turkmenistan; Iran; Turkey; Pakistan; Arabia) } \\
\hline Function 1 & 10.96 & 83.2 & 0.96 & 0.017 & 89.1 & 44 & $\begin{array}{l}\text { condyloba- } \\
\text { sal length }\end{array}$ & 4.98 & $\begin{array}{l}\text { greatest } \\
\text { length }\end{array}$ & 4.33 & $\begin{array}{l}\text { greatest } \\
\text { palatal } \\
\text { breadth }\end{array}$ & 2.11 & 0.000 \\
\hline \multicolumn{14}{|c|}{ Scenario 5. Separation into 5 groups (Caucasus and Turkmenistan; Iran; Turkey and Sinai; Pakistan; Arabia) } \\
\hline Function 1 & 15.11 & 83.9 & 0.97 & 0.009 & 104.0 & 44 & \begin{tabular}{|c|} 
condyloba- \\
sal length
\end{tabular} & 8.47 & $\begin{array}{l}\text { greatest } \\
\text { length }\end{array}$ & 6.06 & $\begin{array}{l}\text { rostrum } \\
\text { breadth }\end{array}$ & 2.86 & 0.000 \\
\hline
\end{tabular}

ern Turkey as expected (Valenciennes, 1856), but also in singular numbers from North Caucasus, south-eastern Azerbaijan, Turkmenistan and some zoos. In 9.4\% of cases information about coloration was not available. The rosettes could be equally large, medium or small and varied even within a single individual. Hair cover also varied significantly from dense and long to short.

\section{Discussion}

As our results show (Fig. 3), the Caucasus and Turkmenistan are inhabited by the same leopard subspecies. Its identity with the leopard from northern Iran is less evident as only one specimen from northern Iran (holotype $P$. p . saxicolor) was available to us in this study. More information from this area would enable to study similarity of leopards from these three regions in more details. It is known, however, that the Caucasus and Turkmenistan populations are linked with the northwestern and north-eastern mountainous regions of Iran and, from a biogeographical standpoint, must be considered as a single population (Lukarevsky, 2001; Khorozyan et al., 2005). According to the article 23 of the International Code of Zoological Nomenclature (ICZN, 1999), the priority name of any taxon is the oldest of all given to it. In case of this region, such a name is the Caucasian leopard $P$. p. ciscaucasica which was first described by Satunin (1914) from a specimen in Kuban region, North Caucasus [Fig. 24, 2 on p. 519 in Dinnik (1914)]. This name is used by a number of authors to designate the leopards living on the Great
Caucasus Ridge of North Caucasus vs. the leopards in the South Caucasus named as Anatolian leopard P. p. tulliana (Dinnik, 1914; Ognev, 1935; Jafarov, 1946; Alekperov, 1947; Burchak-Abramovich \& Jafarov, 1949; Dal, 1954; Sludsky, 1973; Gasparyan \& Agadjanyan, 1974; Gadjiev, 2000). The British mammalogist Pocock (1927) had collected the specimens from different areas of Persia (now Iran) and identified them as belonging to the new Persian subspecies $P$. p saxicolor. He was well-aware of Satunin's description of $P$. p. ciscaucasica and recognized its obvious similarity to $P$. p. saxicolor, but retained the name $P$. p saxicolor pending further information about the Caucasian leopard (see Pocock, 1930a). Heptner \& Sludsky (1972) identified the $P$. p . ciscaucasica and $P$. p saxicolor as synonyms. We claim that the leopard in this region should be named as Caucasian leopard P. p. ciscaucasica.

Ognev (1935) and Burchak-Abramovich \& Jafarov (1949) have noted that the North Caucasus leopards differ from the South Caucasus leopards by smaller skull size, wider zygomatic breadth and narrower frontal breadth but realized that these minor differences could be caused by inadequate sample size as only one skull from South Caucasus was available to them. We have found out that these authors are partially right, but the zygomatic breadth of the North Caucasus leopards is narrower and not wider as these authors noted (see data on Tab. 1). Given the integrity of the leopards from North and South Caucasus under the name P. p. ciscaucasica, this difference in cranial parameters can be considered as a local variation.

The larger skull size of the South Caucasus vs. North Caucasus leopards had led Zukowsky (1964) to 


\section{Scenario 1}

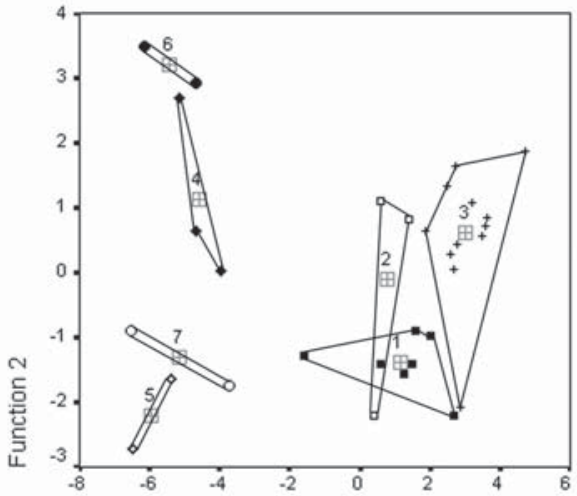

Function 1

Scenario 3

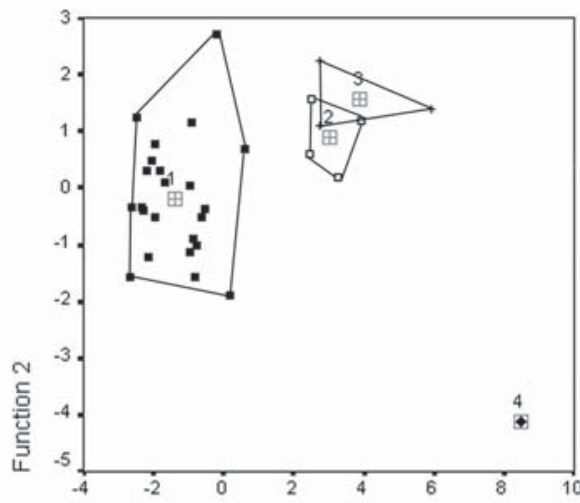

Function 1
Scenario 2
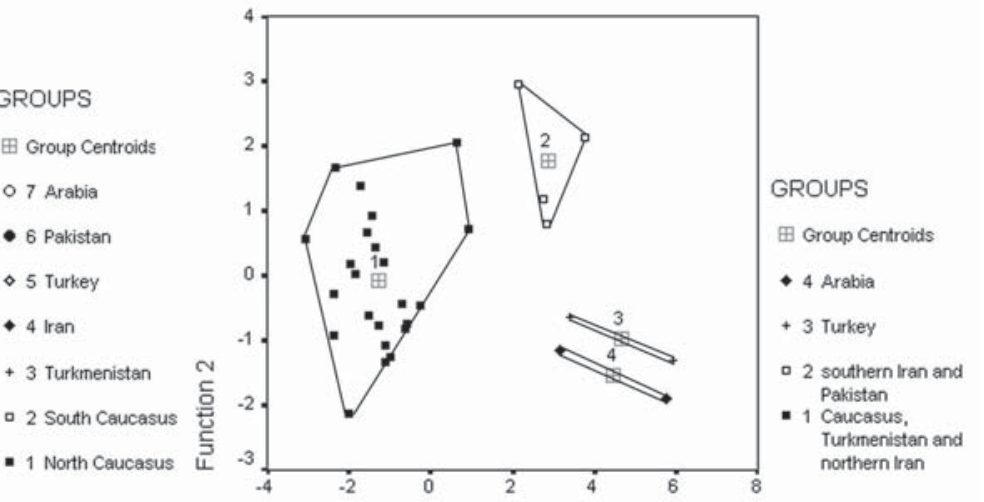

Function 1

Scenario 4

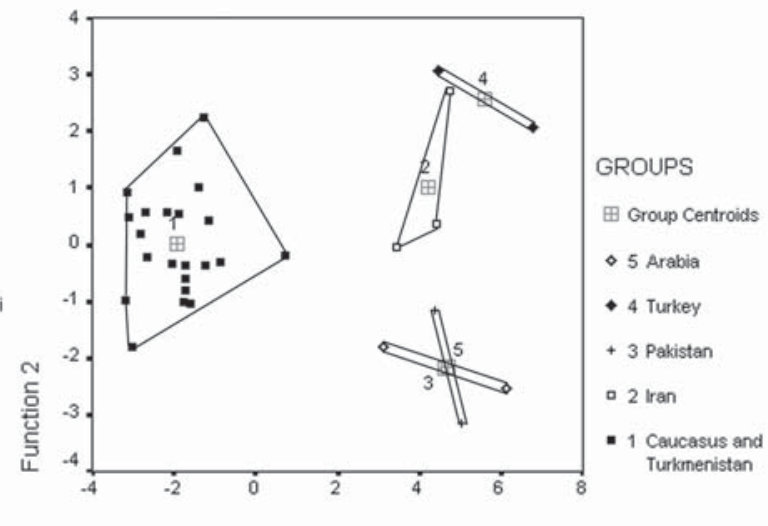

Function 1

Scenario 5

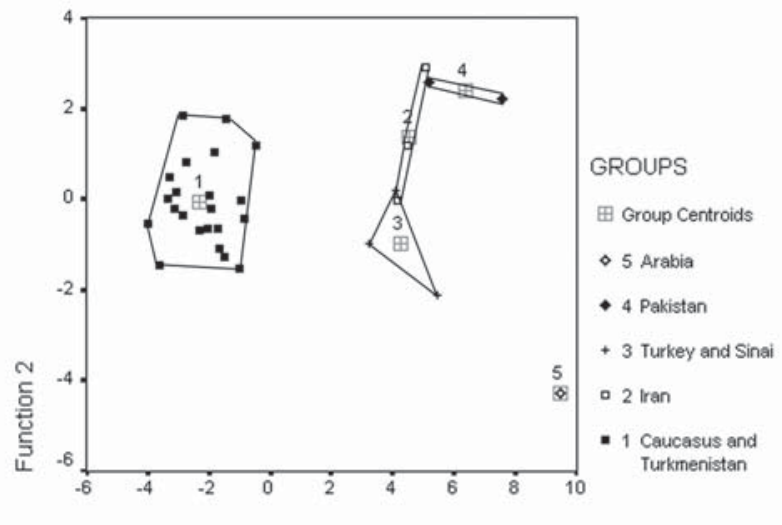

Function 1

Figure 3. The multiple discriminant analysis plots of five scenarios of leopard grouping in the Middle East.

describe the subspecies $P$. p. transcaucasica from the highlands of Georgia, Armenia and Azerbaijan. He referred to Satunin (1905) who provided some parameters of the leopard skulls from Julfa, Erivan Province (JSM 37 and JSM 37a) and, based on their large size, expressed some doubts that the "Erivan" and "Talysh" leopards are identical. No comparative analysis of these skulls with those from Persia or other regions was done. Also, Zukowsky (1964) was incorrect by extending the terra typica from the semi-desert Araks River lowland where Julfa is located to the highlands of South Caucasus. Heptner \& Sludsky (1972) deliberately ignored 
this taxon as inappropriately described and we agree with these authors. We consider the name P. p. transcaucasica as synonym of $P$. p . ciscaucasica.

Contrary to many expectations, the identity of leopards from South Caucasus and other regions, on the one hand, and Asia Minor, on the other hand, as the Anatolian leopard $P$. p. tulliana was not confirmed by this study. This subspecies was described by Valenciennes (1856) from Ninfi, a village not far from the town of Smyrna (now Izmir) in western Turkey. Following him, the researchers began to use this name also for the leopards found beyond Asia Minor, e.g. in the Caucasus and Iraq (Lydekker, 1899; Hatt, 1959). Birula (1912) offered to name all leopards living from Asia Minor through Persia as $P$. p. tulliana. IUCN (2006) considers the Anatolian leopard as living only in the extreme south-west of Turkey where most of previous records of this subspecies come from (Kumerloeve, 1956, 1967). The leopard has gone extinct in Turkey in the mid-1970s (Akin, 1991). We propose to retain the name Anatolian leopard P.p. tulliana for south-western Turkey.

There is no craniological material available from the leopards harvested in eastern Turkey where the ranges of $P$. p. tulliana and $P$. p. ciscaucasica converge which could elucidate the relationship between these two subspecies. That the skins originated from this area have identical pattern adapted to high-elevation conditions is not a taxonomic clue (Borner, 1977). Interestingly, there are no leopard records in central Turkey as all published records of this cat in the country come either from south-western maritime territory (most cases), with some long-distance forays to the south-east and north-west, or from the east (singular cases) (Kumerloeve, 1956, 1967, 1976; Baytop, 1973; Borner, 1977). So, the range disjunction between $P$. p. tulliana and P. p. ciscaucasica in central Asia Minor is possible. Similar pattern of distribution was revealed for subspecies of the brown bear Ursus actos (Baryshnikov, in press).

The Sind or Baluchistan leopard P. p. sindica and Kashmir leopard P. p. millardi were described from two and one skulls, respectively, in Pakistan by Pocock (1930a, b). As shown on Fig. 3, they separate from P. p. ciscaucasica but are seemingly close to the leopard from southern Iran. Possibly, the populations from Baluchistan (southern Iran and southwestern Pakistan) could be proposed as one subspecies $P$. $p$. sindica which had evolved being separated from $P$. p. ciscaucasica by vast Dasht-e Kavir and Dasht-e Lut deserts in central and eastern Iran (Zehzad et al., 2002). We offer to use the names $P$. p . sindica and $P$. p. millardi as synonyms until later studies involving more material from this region provide new results. Meantime, it is reasonable to suppose that the Indus River could act in historical times as a strong barrier to isolate these subspecies in Pakistan, with P. p. sindica closer associated with populations of southern Iran and $P . p$. millardi more related to the leopards of India and Nepal.

Zukowsky (1959) described a new subspecies called by him the Central Persian leopard P. p. dathei and discussed it further in Zukowsky (1964). The description is based on the other person's words that saw two greenish-gray straw-stuffed specimens mounted on a cottage roof in the village Saidabad to the south-east of Shiraz town in Fars Province, southern Iran (Zukowsky, 1959: 342). We believe that these specimens were either aberrant or with artificially changed fur. We have studied two skulls from Fars (see Material and Methods) and found out their closeness to the specimens from southern Pakistan. This linkage deserves further research using more diverse material. The name $P$. p dathei should be considered as synonym of $P$. $p$. sindica.

Until now, Afghanistan was supposed to contain populations of as many as four subspecies ( $P$. p . saxicolor, $P$. p. dathei, $P$. p sindica and P. p. millardi) what is unlikely for such a wide-ranging carnivore as the leopard (Shoemaker, 1993). As no skulls from Afghanistan were at our disposal during this study, the question of the number of leopard subspecies existing in this country would be better left open. Most likely, the north-western areas of Afghanistan are inhabited by $P$. p. ciscaucasica and the southern parts are home for $P$. p. sindica. The taxonomic position of leopard from north-eastern Afghanistan and its relationship with Kashmir leopard P. p. millardi should be clarified.

The liaison of the Sinai leopard P. p. jarvisi and Arabian leopard P. p. nimr is still unclear. In our sample the Sinai female was much larger than the Arabian male leopard so they could belong to different subspecies, especially as the uniqueness of Arabian leopard was recently confirmed on a molecular genetic level (Uphyrkina et al., 2001). We have also found that the Arabian and Sinai leopards are totally separated from all the others in the Middle East (Fig. 3). A similar trend is found in distribution of Arabian subspecies of the honey badger Mellivora capensis which is closer to the African than to the Asian subspecies (Baryshnikov, 2000). The Arabian leopard P. p. nimr was described in 1833 from the vicinities of Al Qunfida, Saudi Arabia (see Harrison \& Bates, 1991). The putative closeness of the Sinai leopard and Anatolian leopard P. p. tulliana (Tab. 2, Fig. 3) is possible due to the convergence of their ranges in Israel (Mendelssohn, 1989). Originally, P. p. jarvisi was described from the Sinai Peninsula (Pocock, 1932) and this form should be comparatively analyzed with nominotypical subspecies $P$. p pardus (L., 1758) whose terra typica was fixed as "Egypt" (Thomas, 1911). The Sinai leopard has become extinct in the mid-1960s (Mendelssohn, 1989).

Naturally, most (if not all) leopard subspecies were recognized on a basis of variation in coat patterns. The features diagnostic for subspecies in the Middle East include the following: large body, bright, rather short fur with tawny tint, large thin-rimmed rosettes, long tail with furry tip for P. p. tulliana; large body, pale, longhaired yellowish skin, medium-sized rosettes and shorter tail for P. p. saxicolor; same as P. p. saxicolor, but smaller body size for $P$. p. ciscaucasica; smaller body size, pale short coat, small thin-rimmed rosettes for $P$. p. nimr; same as $P$. p. nimr, but slightly darker ground 
color and brown spots for $P$. p. jarvisi; coarse, quite pale fulvous-buff skin but richer than in $P$. p. saxicolor with large widely spaced rosettes for $P$. p . sindica; darker grayish-yellow, furry coat with small close-up rosettes for $P$. p. millardi; greenish-gray, short haired skin with much fewer and small rosettes for P. p. dathei; large body, short and bright buff or tawny skin for $P$. $p$. transcaucasica (Valenciennes, 1856; Dinnik, 1914; Satunin, 1914, 1915; Ognev, 1935; Borner, 1977; Pocock, 1930a, b; Zukowsky, 1959; Mendelssohn, 1989; Harrison \& Bates, 1991).

The coat pattern characteristics used to distinguish felid subspecies are subjective and variable and thus unlikely to be a reliable tool, in opposite to felid species which have the specific patterns of taxonomic and phylogenetic importance (Werdelin \& Olsson, 1997). In Iran alone, the leopards can be of light grayish phase in the north-west and darker buff phase in the north-east (Heptner \& Sludsky, 1972). Our analysis of coat variation in animals from many areas of the Middle East has revealed high individual variability in coloration. The coat patterns of felids have been evolved to ensure adaptation by gaining camouflage, optimal thermoregulation and other features that contribute to their survival in a given environment (Ortolani, 1999). Thus, the long-haired grayish coats are characteristic for the leopards living in high mountains with strict continental climate and the short-haired bright coats of deeper tawny coloration are peculiar to inhabitants of humid and warm subtropical habitats at lower elevations. Variation in hair cover is most likely a result of seasonal changes.

As the leopard is on the brink of extinction in most areas of the Middle East, large-scale efforts on its conservation must focus on the vast area which covers the Caucasus, northern Iran and Turkmenistan and is inhabited by one endangered subspecies, the Caucasian leopard $P$. p. ciscaucasica.

ACKNOWLEDGMENTS. This article constitutes a part of I.G. Khorozyan's PhD dissertation at the Zoological Institute, Russian Academy of Sciences (Saint-Petersburg, Russia). We thank Dr. A.N. Tikhonov (ZIN), Dr. S.V. Kruskop (ZMMU), Dr. P. Jenkins (NHM), Dr. N.U. Manaseryan and Dr. M.S. Adamyan (Institute of Zoology, National Academy of Sciences, Yerevan, Armenia) for valuable assistance during the skull and skin research at their institutions. We also appreciate assistance provided by B. Lortkipanidze (NACRES, Georgia), O. Shilo (Novosibirsk Zoo, Russia), G. Peters (Zoologisches Forschungsinstitut und Museum Alexander Koenig, Germany), P. Jackson (Cat Specialist Group, UK), B. Kiabi (Shahid Beheshti University, Iran), E. Askerov (WWF, Azerbaijan) and M. Raffel (Allwetter Zoo, Germany) who provided information and granted us the leopard pictures for the coat pattern studies. G.F. Baryshnikov obtained financial support for his visit to the Natural History Museum in London from the Royal Society (UK).

\section{References}

Akin A. 1991. The status of the leopard in Turkey // 1990 International Leopard Studbook. P.7-10.
Alekperov A.M. 1947. [New data about the South Caucasus leopard (Panthera pardus tullianus Valenc.)] // Doklady Akademii Nauk Azerbaidzhanskoi SSR. Vol.3. No.3. P.126-128 [in Russian].

Anonymous. 1991. The subspecies question // Cat News. No.15. P.17-18.

Baryshnikov G. 2000. A new subspecies of the honey badger Mellivora capensis from Central Asia // Acta Theriologica. Vol.45. No.1. P.45-55.

Baryshnikov G.F. in press. [Fauna of Russia and Adjacent Territories. Mammals. Vol.1. Part 5.Family Ursidae]. Sankt-Peterburg: Nauka. [in Russian].

Baytop T. 1973. Neue Beobachtungen über die Verbreitung des kleinasiatischen Leoparden (Panthera pardus tulliana) in der Türkei // Bonner Zoologische Beiträge. Bd.24. Hf.3. S.183-184.

Birula A.A. 1912. [Materials on systematics and geographical distribution of mammals. III. Carnivora collected by N.A. Zarudny in Persia in 1896, 1898, 1900--1901, and 1903-1904] // Ezhegodnik Zoologicheskogo Muzeya Imperatorskoi Akademii Nauk. No.17. P.219-280 [in Russian].

Borner M. 1977. Leopards in western Turkey // Oryx. Vol.14. No.1. P.26-30.

Burchak-Abramovich N.O. \& Jafarov R.D. 1949. [The leopard (Panthera pardus tullianus Valenc.) on Apsheron Peninsula] // Trudy Estestvenno-istoricheskogo Muzeya Akademii Nauk Azerbaidzhanskoi SSR. No.3. P.86-104 [in Russian].

Dal S.K. 1954. [Animal World of Armenian SSR. Vol.1. Vertebrates]. Yerevan: Izdatel'stvo Akademii Nauk Armyanskoi SSR. 415 p. [in Russian]

Dinnik N.Ya. 1914. [Mammals of the Caucasus. Part II. Carnivores]. Tiflis: Tipografiya K.P. Kozlovskogo. 537 p. [in Russian].

Gadjiev D.V. 2000. [Leopard - Panthera pardus L.] // Kerimly T. (ed.). [Animal World of Azerbaijan. T.3]. Baku: Elm. P.577-578 [in Russian].

Gasparyan K.M. \& Agadjanyan F.S. 1974. [On the leopard in Armenia] // Biologicheskii Zhurnal Armenii. T.27. No.12. P.84-88 [in Russian].

Harrison D.L. \& Bates P.J.J. 1991. The Mammals of Arabia. Second Edition. Sevenoaks: Harrison Zoological Museum Publication. 354 p.

Hatt R.T. 1959. The mammals of Iraq // Miscellaneous Publications of the Museum of Zoology, University of Michigan. No.106. P.1-113.

Heptner V.G. \& Sludsky A.A. 1972. [Mammals of the Soviet Union. Vol.2. Part 2. Carnivores (Hyenas and Cats)]. Moskva: Vysshaya Shkola. 551 p. [in Russian]

ICZN. 1999. International Code of Zoological Nomenclature. Fourth Edition. London: International Trust of Zoological Nomenclature. $306 \mathrm{p}$.

IUCN. 2006. The 2006 IUCN Red List of Threatened Species. $<$ www.iucnredlist.org $>$

Jafarov R.D. 1946. [The leopard (Felis pardus L.) on Apsheron] // Izvestiya Akademii Nauk Azerbaidzhanskoi SSR, Otdelenie Geologo-khimicheskikh Nauk i Nefti. T.2. No.6. P.106-107 [in Russian].

Khorozyan I.G. \& Abramov A.V. 2005. [The spatial structure and conservation of the Persian leopard population 
in Armenia] // Rozhnov V.V. \& Tembotova F.A. (eds.). [Mammals of the Mountainous Areas]. Moskva: KMK Scientific Press. P.199-202 [in Russian].

Khorozyan I., Malkhasyan A. \& Asmaryan S. 2005. The Persian leopard prowls its way to survival // Endangered Species Update. Vol.22. No.2. P.51-60.

Kiabi B.H., Dareshouri B.F., Ghaemi R.A. \& Jahanshahi M. 2002. Population status of the Persian leopard (Panthera pardus saxicolor Pocock, 1927) in Iran // Zoology in the Middle East. No.26. P.41-47.

Kumerloeve H. 1956. Zur Verbreitung des Leoparden (Panthera pardus L.) in Anatolien // Der Zoologische Garten, Neue Folge. Bd.22. Hf.2. S.154-162.

Kumerloeve H. 1967. Zur Verbreitung kleinasiatischer Raubund Huftiere sowie einiger Großnager // Säugetierkundliche Mitteilungen. Bd.15. Hf.4. S.337-409.

Kumerloeve H. 1976. Leoparden, Panthera pardus tulliana (Valenciennes, 1856), in Zentralanatolien // Säugetierkundliche Mitteilungen. Bd.24. Hf.1. S.46-48.

Larson S.E. 1997. Taxonomic re-evaluation of the jaguar // Zoo Biology. No.16. P.107-120.

Lukarevsky V.S. 2001. [The Leopard, Striped Hyena, and Wolf in Turkmenistan]. Moskva: Signar. 128 p. [in Russian]

Lukarevsky V.S. 2006. [The spotted hostage. Home for the leopard] // Panda Times. May 2006. P.8-9 [in Russian].

Lukarevsky V., Askerov E. \& Hazaryan G. 2004. Condition of the leopard population in the Caucasus // Beiträge zur Jagd- und Wildforschung. No.29. P.305-319.

Lydekker R. 1899. On the leopard of the Caucasus // Proceedings of the Zoological Society of London. P.795-796.

Meijaard E. 2004. Biogeographic history of the Javan leopard Panthera pardus based on a craniometric analysis // Journal of Mammalogy. Vol.85. No.2. P.302-310.

Mendelssohn H. 1989. Felids in Israel // Cat News. No.10. P.2-4.

Miththapala S. 1992. Genetic and Morphological Variation in the Leopard (Panthera pardus): a Geographically Widespread Species. PhD Thesis. Gainesville: University of Florida.

Miththapala S., Seidensticker J. \& O’Brien S.J. 1996. Phylogeographic subspecies recognition in leopards (Panthera pardus): molecular genetic variation // Conservation Biology. Vol.10. No.4. P.1115-1132.

O’Brien S.J. \& Mayr E. 1991. Bureaucratic mischief: recognizing endangered species and subspecies // Science. Vol.251. No.4998. P.1187-1188.

Ognev S.I. 1935. [Mammals of the USSR and Adjacent Countries. T.3. Carnivores and Pinnipeds). Moskva-Leningrad: Biomedgiz. 752 p. [in Russian]

Ortolani A. 1999. Spots, stripes, tail tips and dark eyes: predicting the function of carnivore colour patterns using the comparative method // Biological Journal of the Linnean Society. Vol.67. No.4. P.433-476.

Pocock R.I. 1927. Description of two subspecies of leopards // Annals and Magazine of Natural History, Series 9. No.20. P.213-214.

Pocock R.I. 1930a. The panthers and ounces of Asia // Journal of the Bombay Natural History Society. Vol.34. No.1. P.65-82.

Pocock R.I. 1930b. The panthers and ounces of Asia. Part II. The panthers of Kashmir, India, and Ceylon // Journal of the Bombay Natural History Society. Vol.34. No.2. P.307-336.

Pocock R.I. 1932. The leopards of Africa // Proceedings of the Zoological Society of London. No.2. P.542-591.

Puzachenko A.Yu. 1993. On the taxonomic status of Felis silvestris Schreber, 1777 on the Caucasus with some comments on the variation between the European and the African wildcat // Proceedings of the Seminar on Biology and Conservation of the Wildcat (Felis silvestris), Nancy, France. Strasbourg: Council of Europe. P.75-81.

Quinn G.P. \& Keough M.J. 2002. Experimental Design and Data Analysis for Biologists. Cambridge: Cambridge University Press. 537 p.

Raffel M. 2004. Persian Leopard (Panthera pardus saxicolor) EEP Annual Report 2004. Munster: Allwetter Zoo. 17 p.

Satunin K.A. 1905. [The mammals of Talysh and Mugan] // Izvestiya Kavkazskogo Muzeya. T.2. No.2-4. P.87-402 [in Russian].

Satunin K.A. 1914. [Key of the Mammals of the Russian Empire. T.1. Chiroptera, Insectivora, and Carnivora]. Tiflis: Tipografiya kantseliarii namestnika E.I.V. na Kavkaze. 184 p. [in Russian]

Satunin K.A. 1915. [Mammals of the Caucasus Region. T.1. Chiroptera, Insectivora, and Carnivora] // Zapiski Kavkazskogo Muzeya, Seriya A. No.1. P.1-410 [in Russian].

Shoemaker A.H. 1993. The Status of the Leopard, Panthera pardus, in Nature: A Country by Country Analysis. Columbia SC: Riverbanks Zoological Park. 51 p.

Sludsky A.A. 1973. [Distribution and abundance of wild cats in the USSR] // Trudy Instituta Zoologii Akademii Nauk Kazakhskoi SSR. No.34. P.5-106 [in Russian].

Thomas O. 1911. The mammals of the tenth edition of Linnaeus; an attempt to fix the types of the genera and the exact bases and localities of the species // Proceedings of the Zoological Society of London. P.120-158.

Uphyrkina O., Johnson W.E., Quigley H., Miquelle D., Marker L., Bush M. \& O’Brien S.J. 2001. Phylogenetics, genome diversity and origin of modern leopard, Panthera pardus // Molecular Ecology. Vol.10. No.11. P. 2617-2633.

Valenciennes M.A. 1856. Sur une nouvelle espèce de Panthère tuée par M. Tchihatcheff à Ninfi, village situé à huit lieues est de Smyrne // Comptes Rendus Hebdomadaires des Séances de l'Académie des Sciences. No.42. P.1035-1039.

Werdelin L. \& Olsson L. 1997. How the leopard got its spots: a phylogenetic view of the evolution of felid coat patterns // Biological Journal of the Linnean Society. Vol.63. No.3. P.383-400.

Yamaguchi N., Driscoll C.A., Kitchener A.C., Ward J.M. \& Macdonald D.W. 2004. Craniological differentiation between European wildcats (Felis silvestris silvestris), African wildcats (F. s. lybica) and Asian wildcats (F. s. ornata): implications for their evolution and conservation // Biological Journal of the Linnean Society. Vol.83. No.1. P.47-63.

Zehzad B., Kiabi B.H. \& Madjnoonian H. 2002. The natural areas and landscapes of Iran: an overview // Zoology in the Middle East. No.26. P.7-11.

Zukowsky L. 1959. Persische Panther // Der Zoologische Garten, Neue Folge. Bd.24. Hf.5-6. S.329-344.

Zukowsky L. 1964. Weitere Mitteilungen über Persische Panther // Der Zoologische Garten, Neue Folge. Bd.28. Hf.4. S.151-182. 